\title{
CD4 + Cells Treated with DNA Methylation Inhibitors Induce Autologous B Cell Differentiation
}

\author{
Bruce C. Richardson, Michael R. Liebling, and Jerry L. Hudson \\ University of Michigan, Ann Arbor. Michigan $48109-0531$ and the UCLA School of Medicine. \\ Los Angeles, California 90024
}

\begin{abstract}
The DNA methylation inhibitor 5-azacytidine induces atoreactivity in cloned CD4 $T$ cells, but the functional consequences of this response are unknown. We now report that CD4 + T cells treated with 5-azacytidine respond to autologous antigen-presenting cells and induce autologous $B$ cell differentiation without exogenous antigen or mitogen. This mechanism could play a role in some autoimmune diseases characterized by $T$ cell DNA hypomethylation and polyclonal B cell activation. 1990 Academic Press. Inc.
\end{abstract}

\section{INTRODUCTION}

Despite extensive study, the basic immune mechanism(s) causing lupus remains unknown. The murine chronic graft-versus-host model demonstrates that alloreactive $\mathrm{CD} 4+\mathrm{T}$ cells responding to host class II MHC molecules in wivo can produce a disease resembling systemic lupus erythematosus (SLE) $(1,2)$, leading some authors to speculate that autoreactive CD4 + cells with class II specificity may cause human SLE by a similar mechanism (3). These autoreactive cells have been sought in SLE patients using the autologous mixed lymphocyte reaction (AMLR), with largely negative results (4-7). Despite this, the concept that autoreactive T cells cause SLE remains attractive since autoreactive cells may be distributed in locations other than peripheral venous blood, such as lymphatic tissue, or the autoreactive cells may be refractory to restimulation in vitro (8), preventing their detection.

Our group has found indirect cvidence that autoreactive $T$ cells may be involved in the pathogenesis of human SLE. We have reported that cloned antigen-specific $\mathrm{T}$ cells can become autoreactive following treatment with the DNA methylation inhibitor 5-azacytidine (5-azaC) (9). Procainamide, which induces a SLE-like syndrome in some patients, also induces autoreactivity in cloned $\mathrm{T}$ cells and inhibits DNA methylation $(10,11)$. Furthermore, patients with active idiopathic SLE have recently been found to have hypomethylated T cell DNA (12). These results suggest an association between DNA hypomethylation, $T$ cell autoreactivity, and SLE, and provide a model in which DNA hypomethylation predisposes to T cell autoreactivity, possibly by modifying gene expression, and the autoreactive $\mathrm{T}$ cells participate in the pathogenesis of the autoimmune disease. However, the functional consequences of 5 -azaC-induced $\mathrm{T}$ cell autoreactivity have not been defined.

The cellular immune abnormalities characterizing SLE include peripheral venous $B$ cells actively secreting immunoglobulin and $T$ cells bearing activation markers (13-16). The autoreactive and chronic graft-versus-host models provide 
an explanation for the $T$ cell activation since in both models $T$ cells could be activated by class II MHC determinants on B cells, macrophages, or other class II bearing cells. The murine chronic graft-versus-host disease model also predicts that autoreactive $T$ cells should be able to induce autologous $B$ cells to differentiate into immunoglobulin-secreting cells, some secreting autoantibodies $(2,17)$.

We now report testing the autoreactive model by treating interleukin (IL)2-dependent $\mathrm{CD} 4+\mathrm{T}$ cell lines with DNA methylation inhibitors, then asking whether the treated cells cause autologous B cells to differentiate into immunoglobulin-secreting cells.

\section{MATERIALS AND METHODS}

\section{$T$ Cell Lines}

Peripheral blood mononuclear cells (PBMC) were isolated by density gradient centrifugation as described (9). To obtain CD4 + and CD8 + subsets, $20 \times 10^{6}$ freshly isolated PBMC were suspended in $0.5 \mathrm{ml}$ RPMI 1640 and $5 \mu \mathrm{g}$ OKT4 or OKT8 (Ortho Pharmaceuticals, Raritan, NJ) was added. The cells and monoclonal antibodies $(\mathrm{mAb})$ were incubated at $4^{\circ} \mathrm{C} 15 \mathrm{~min}$ prior to the addition of $0.5 \mathrm{ml}$ rabbit complement (Pel-Freeze, Brown Deer, WI). The mixture was incubated at $37^{\circ} \mathrm{C}$ for $45 \mathrm{~min}$, the cells were then washed twice in HBSS (GIBCO, Grand Island, NY). This treatment was repeated once. T cells were activated with $0.5-$ $1.0 \mu \mathrm{g} / \mathrm{ml}$ phytohemagglutinin (PHA) (Burroughs Wellcome, Greenville, $\mathrm{NC}$ ) in RPMI 1640 containing $10 \%$ fetal calf serum (FCS) (HyClone, Logan, UT), 100 $\mathrm{U} / \mathrm{ml}$ penicillin, and $100 \mu \mathrm{g} / \mathrm{ml}$ streptomycin, and expanded in the same media supplemented with IL-2 (conditioned media from MLA-144 cells) (18). Lines were cultured in 24-well plates (Nunc, from GIBCO) and were restimulated weekly by adding $10^{6}$ irradiated $(2000 \mathrm{R})$ autologous PBMC to serve as APC plus $10 \mathrm{ng} / \mathrm{ml}$ OKT3 (Ortho Pharmaceuticals). Fresh IL-2 was added twice weekly.

\section{Pharmacologic Modification of T Cells}

5-azaC, hydroxyurea, procainamide (all from Sigma Chemical Co., St. Louis, $\mathrm{MO}$ ), and $\mathrm{N}$-acetylprocainamide (Napa) (Aldritch Chemical Co., Milwaukee, WI) were added to proliferating $T$ cells, and 6-8 days later the cells were washed and used for flow cytometry, proliferation, or B cell differentiation assays.

\section{Flow Cytometric Analysis}

Fluorescein conjugates of anti-CD4, anti-CD8, anti-2H4, and anti-4B4 were purchased from Coulter (Hialeah, FL). Cells were stained with these reagents and analyzed on an EPICS V flow cytometer as previously described (19).

\section{Proliferation Assay}

$\mathrm{T}$ cell proliferation was determined by tritiated thymidine $\left(\left[{ }^{3} \mathrm{H}\right] \mathrm{TdR}\right)$ incorporation as previously described $(9-11)$. Briefly, $\mathrm{T}$ cells were washed free of IL-2 and were cultured $16 \mathrm{hr}$ in RPMI/10\% FCS. T cells $\left(2 \times 10^{4}\right)$ were then cultured with $10^{5}$ freshly isolated autologous irradiated $(2000 \mathrm{R})$ PBMC in $200 \mu \mathrm{l}$ of RPMI/10\% FCS. Two days later, $0.5 \mu \mathrm{Ci}$ of $\left[{ }^{3} \mathrm{H}\right] \mathrm{TdR}$ (New England Nuclear, 
Boston, MA) was added to each well, and $18 \mathrm{hr}$ later the cells were harvested and ${ }^{3} \mathrm{H}$ incorporation into DNA was determined. All assays were performed in quadruplicate. In some experiments $T$ cells were not precultured in the absence of IL-2. In these experiments, proliferation was measured 3 days after setting up the assay. No significant differences were observed between the two methods.

\section{B Cell Differentiation Assay}

All studies were performed with autologous B cells. B cells were isolated from PBMC by depletion of adherent and rosette-forming cells as previously described and are routinely $>95 \% \mathrm{Ig}+(20)$. For assay, IL-2-dependent $\mathrm{T}$ cell lines were washed free of IL-2 and cultured in RPMI/10\% FCS for 1-2 days. T cells $\left(5 \times 10^{4}\right)$ were then cultured with $1.25 \times 10^{4}$ freshly isolated autologous B cells in flatbottomed microtiter wells containing $0.2 \mathrm{ml} \mathrm{RPMI} / 10 \% \mathrm{FCS}$. All cultures were performed in quadruplicate. The cultures were fed with an additional $50 \mu \mathrm{l}$ of RPMI/10\% FCS on Days 4 and 8, and on Day 10 the supernatants were harvested and stored at $-20^{\circ} \mathrm{C}$ until assayed for immunoglobulin.

\section{Antibody Assays}

IgG and IgM in culture supernatants were measured by ELISA as described previously (20). The radioimmunoassay for anti-DNA antibodies was performed as previously published (21), and the radioimmunoassay for anti-histone antibody assay was performed according to the method of Rubin et al. (22). The ELISA for antilymphocyte antibodies was performed by washing CD4 +, IL-2-dependent $T$ cells, then pipetting $5 \times 10^{5}$ cells into flat-bottom 96-well Immulon plates (Nunc. from GIBCO). The plates were centrifuged at $100 \mathrm{~g}$ for $5 \mathrm{~min}$, the media discarded, and the cells fixed with $1 \%$ glutaraldehyde in $0.01 M \mathrm{PO}_{4}, \mathrm{pH} 7.4,0.9 \% \mathrm{NaCl}$ (PBS) for 15 min at $25^{\circ} \mathrm{C}$. After three washes with PBS the wells were filled with $100 \mu \mathrm{l}$ of $2 \%$ bovine serum albumin (BSA) (Sigma) in PBS for $1 \mathrm{hr}$, then antibody containing supernatants or serial dilutions of anti-CD2 $\mathrm{mAb}$ (Ortho Pharmaceuticals, Raritan, NJ) were added in $2 \% \mathrm{BSA} / \mathrm{PBS}$ and incubated at $4^{\circ} \mathrm{C}$ overnight. The plates were washed with PBS again, then $80 \mu \mathrm{l}$ protein A-alkaline phosphatase (Sigma) diluted 1:500 in 0.234 $M$ Tris, pH 8.0, 0.1 $\mu M \mathrm{MgCl}_{2}, 3 \mu M \mathrm{NaN}_{3}$, $1 \%$ hen egg albumin (Sigma) was added for $1 \mathrm{hr}$. After three washes, $100 \mu \mathrm{l}$ phosphatase substrate (Sigma) was added at $1 \mathrm{mg} / \mathrm{ml}$ in $0.025 M$ carbonate buffer, $\mathrm{pH} 9.8$, and the plates were incubated at $37^{\circ} \mathrm{C}$ until a color change was apparent. The plates were read at $405 \mathrm{~nm}$ on a Titertek Multiskan ELISA plate reader.

\section{Monoclonal Antibodies}

The anti-class I mAb, specific for nonpolymorphic MHC determinants, was purchased from Cappel Laboratories (Cochranville, PA). The anti-class II mAb, 9.49 (23), and the control NS-1 ascites were a generous gift from Dr. Robert Todd, III.

\section{Statistical Analysis}

The difference between means was compared using Student's $t$ test and all experiments were repeated two to five times. 


\section{RESULTS}

\section{5-azaC-Treated CD4 + Cells Respond to Autologous APC}

Polyclonal T cells were chosen for these studies, rather than cloned tetanus toxoid reactive cells, to more closely approximate in vivo immune responses. We first established that 5-azaC-treated polyclonal $\mathrm{T}$ cells could respond to autologous PBMC. Interleukin-2-dependent, proliferating, polyclonal CD4 + and CD8 + cell lines were treated with $1 \mu M$ 5-azaC for 6-8 days, then challenged with irradiated (2000 R) autologous PBMC. The optimal concentration for inducing autoreactivity was previously shown to be $1 \mu M 5$-azaC (9). Proliferation was measured 3 days later by $\left[{ }^{3} \mathrm{H}\right] \mathrm{TdR}$ incorporation. The results of two experiments are shown in Table 1. A small proliferative response to irradiated PBMCs was observed in all lines and presumably represents the AMLR. 5-azaC treatment markedly increased the proliferative response of CD4+ but not CD8 + cells to autologous PBMC. The proliferative response to anti-CD3 mAbs was used as a positive control in these experiments, and within each experiment the response to anti-CD3 was not significantly different among the lines.

To test whether class II MHC determinants were required for the CD4 + response, activation of treated CD4 + cells by irradiated autologous APC was inhibited with varying amounts of mAb to class I or class II determinants or a control murine ascites (Fig. 1). Anti-class II mAbs were found to abrogate the response, while similar concentrations of control ascites did not, and $\mathrm{mAb}$ to class I determinants in concentrations as high as $100 \mathrm{ng} / \mathrm{ml}$ did not significantly inhibit.

TABLE 1

Response of 5-azaC-Treated T Cell Subsets to Autologous APC

\begin{tabular}{cccr} 
& & \multicolumn{2}{c}{ Response $(\mathrm{cpm} \pm \text { SEM })^{b}$} \\
\cline { 3 - 4 } Experiment & Cells $^{a}$ & \multicolumn{1}{c}{ Control } & \multicolumn{1}{c}{5 -azaC } \\
\hline 1 & CD8 & $2557 \pm 322$ & $3692 \pm 532$ \\
& CD4 & $2037 \pm 462$ & $18081 \pm 782$ \\
2 & CD8 & $2727 \pm 742$ & $1357 \pm 742$ \\
& CD4 & $2265 \pm 70$ & $8723 \pm 594$ \\
\hline
\end{tabular}

Note. IL-2-dependent T cell lines were treated with $1 \mu M$ 5-azaC and 6-8 days later 20,000 T cells were challenged with $10^{5}$ irradiated autologous PBMC as described under Materials and Methods. Proliferation was measured by $\left[{ }^{3} \mathrm{H}\right] \mathrm{TdR}$ incorporation, and results are expressed as the means $\pm \mathrm{SEM}$ of quadruplicate determinations.

"Percentage CD4- and CD8-bearing cells was determined by flow cytometric analysis. In Experiment 1 , the CD8 line contained $86 \%$ CD8 + and 7\% CD4 + cells, and the CD4 line contained $96 \%$ CD4 + and 1\% CD8 + cells. In Experiment 2, the CD8 line contained 99\% CD8 + cells, while the CD4 line had $7 \% \mathrm{CD} 8+$ cells.

${ }^{b}$ The response of control (untreated) or 5-azaC-treated T cells to irradiated PBMC alone is shown. Positive controls consisted of the response to PBMC plus anti-CD3 antibodies. The response to anti-CD3 was comparable in the experimental lines and was 16,625 \pm 1292 in Experiment 1 and 8808 \pm 431 in Experiment 2 (mean \pm SEM of the four determinations). Similarly, $\left[{ }^{3} \mathrm{H}\right] \mathrm{TdR}$ uptake by $\mathrm{T}$ cells cultured alone was $408 \pm 156$ in Experiment 1 and $625 \pm 413$ in Experiment 2 . 


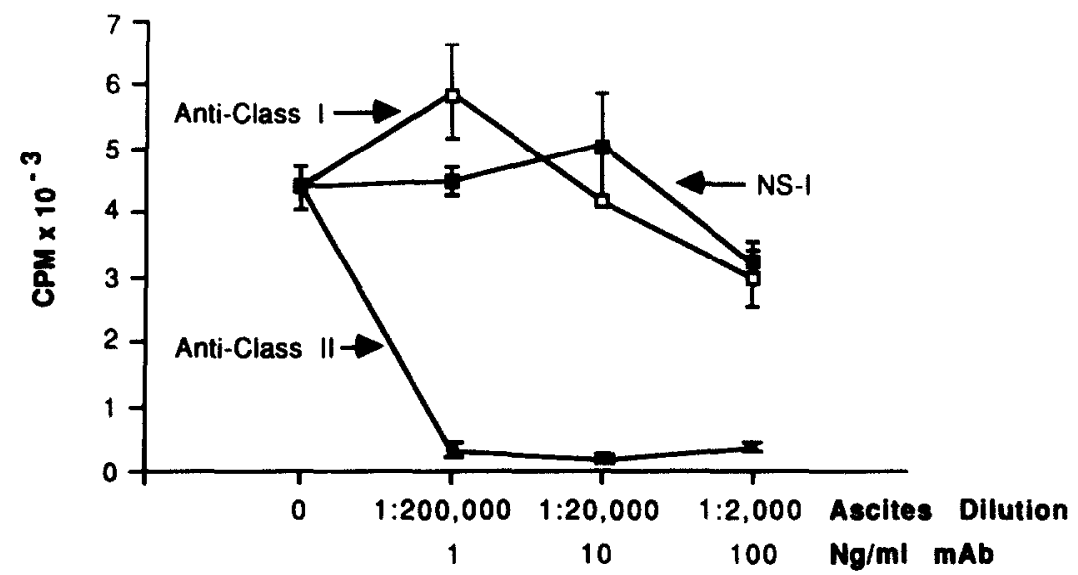

FIG. 1. Anti-class II mAb inhibit 5-azaC-induced autoreactivity. IL-2-dependent CD4 + cells were treated with $1 \mu M$ 5-azaC and harvested 6 days later. Treated cells $\left(2 \times 10^{4}\right)$ were then challenged with $10^{5}$ irradiated autologous PBMC in the presence of the indicated concentrations of mAbs. The anticlass I was purchased in purified form and is quantitated in nanograms per milliliter, while the ascites form of the anti-class II mAb and control NS-1 fusion line ascites were quantitated by dilution. Proliferation was measured by $\left[{ }^{3} \mathrm{H}\right] \mathrm{TdR}$ incorporation and is expressed as the mean cpm $\pm \mathrm{SEM}$ of quadruplicate determinations.

\section{Effect of 5-azaC-Treated CD4 + Cells on CD8+Cells}

Since 5-azaC did not alter CD8 + reactivity, we asked whether CD4 + cells could provide help for an autologous response by CD8 + cells. 5-azaC-treated CD4 and CD8 cells were mixed in variable ratios and were then challenged with irradiated autologous PBMC (Fig. 2). CD8 + cells decreased the CD4 response to PBMC, but did not augment or diminish the response beyond that expected by diluting the CD4 + cells. In these experiments, anti-CD3-induced proliferation was used again as a positive control, and the response to anti-CD3 was similar among the lines. Identical results were observed mixing untreated IL-2-dependent CD8 + cells with 5-azaC-treated CD4 + cells.

\section{Effect of 5-azaC on $2 H 4(C D 45 R)$ and $4 B 4(C D w 29)$ Expression}

The response of 5-azaC-treated CD4 + cells to autologous PBMC resembles the AMLR, which is also a $T$ cell response to autologous non- $T$ cells without added antigen (24). Recent reports indicate that AMLR responsive cells are mainly found in the $\mathrm{CD} 4+2 \mathrm{H} 4+$ subset (25). To test whether 5-azaC selects for the $2 \mathrm{H} 4$ + subset, the $\mathrm{CD} 4+$ line was treated with 0.25-2.0 $\mu M$ 5-azaC and 6 days later was tested for $2 \mathrm{H} 4$ and $4 \mathrm{~B} 4$ expression by flow cytometric analysis (Fig. 3). Six days was previously shown to be the optimal time to detect 5-azaC-induced changes in $\mathrm{T}$ cells (19). The untreated $\mathrm{CD} 4+$ line was primarily $2 \mathrm{H} 4-.5$-azaC caused a small dose-dependent decrease in 4B4 expression, but did not increase $2 \mathrm{H} 4$ expression. 


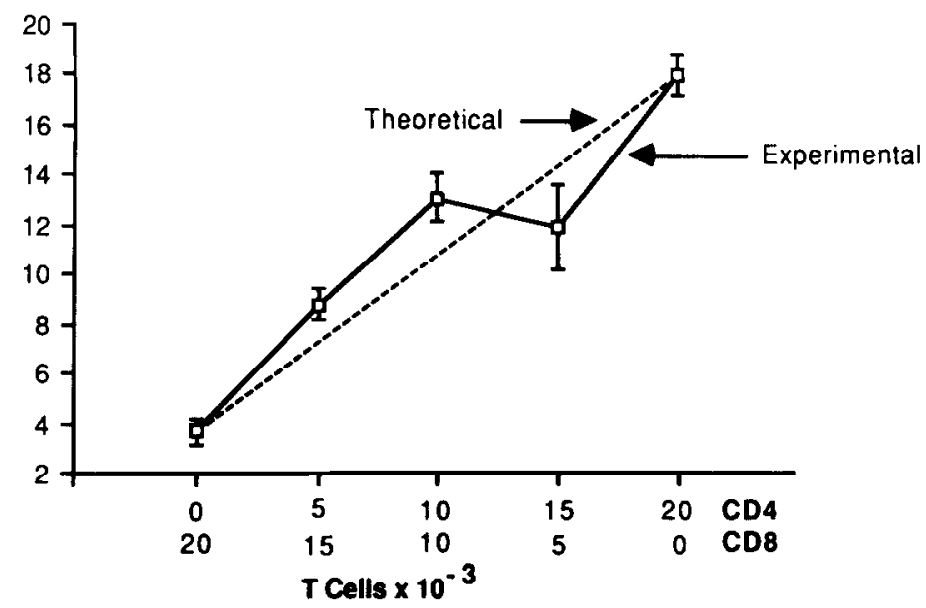

FIG. 2. Effect of mixing 5-azaC-treated CD4 + and CD8 + cells on autoreactivity, IL-2-dependent CD4 and CD8 cell lines were treated with 5-azaC as described in Fig. 1. The cells were mixed in the proportions indicated on the abscissa and challenged with $10^{5}$ irradiated autologous PBMC. Proliferation was measured by $\left.{ }^{3} \mathrm{H}\right] \mathrm{TdR}$ incorporation and results are presented as the means \pm SEM of quadruplicate determinations. The response of the CD4 line to $10^{5} \mathrm{PBMC}$ pius anti-CD3 $(10 \mathrm{ng} / \mathrm{ml})$ was $14,304 \pm 452 \mathrm{cpm}$ and the response of the CD8 line to the same challenge was $19,409 \pm 2615 \mathrm{cpm}$. $\left[{ }^{3} \mathrm{H}\right] \mathrm{TdR}$ uptake by $\mathrm{CD} 4$ cells cultured alone was $106 \pm 54 \mathrm{cpm}$, while uptake by the CD8 cells was 621 \pm 312 . Flow cytometric analysis showed that the CD4 line contained $96 \% \mathrm{CD} 4+$ cells and the CD8 line had $86 \% \mathrm{CD} 8+$ cells. The line labeled "theoretical" connects the proliferative response of CD4 + and CD8 + cells cultured separately and represents the results predicted if CD8 + cells were inert in this system, and simply diluted the CD4 + population.

\section{CD4 + Cells Treated with DNA Methylation Inhibitors Induce Autologous B Cell Differentiation}

To test whether CD4 + and CD8 + cells treated with DNA methylation inhibitors induced autologous B cell differentiation, CD4 + and CD8 + lines were treated with $0.25-2.0 \mu M 5$-azaC, and 6 days later the cells were cultured for an additional 2 days without IL-2, then cultured with freshly isolated autologous B cells without added antigen or mitogen. Ten days later the supernatants were harvested and secreted IgG was measured by ELISA (Fig. 4). Untreated CD4 + cells induced secretion of approximately $19 \mathrm{ng} / \mathrm{ml} \mathrm{IgG}$. In contrast, CD $4+$ cells treated with $1 \mu M 5$-azaC induced secretion of $565 \mathrm{ng} / \mathrm{ml} \mathrm{IgG}$. Treated CD8 + cells did not induce significant IgG secretion. To exclude the possibility that the IgG measured reflected B cell lysis and release of presynthesized IgG rather than B cell activation, B cells were frozen and thawed and released IgG was measured. Under conditions similar to those of the culture system, lysed B cells released 4.9 $\pm 0.4 \mathrm{ng} / \mathrm{ml} \mathrm{IgG}$.

To examine whether $B$ cell differentiation required direct T-B contact or could be mediated via secreted lymphokines, IL-2-dependent CD4 + cells treated with $1 \mu M 5$-azaC and untreated control lines were washed free of IL-2 and were cultured in RPMI containing 10\% FCS but no IL-2. Two days later the cells were removed by centrifugation and $0.2 \mathrm{ml}$ of the lymphokine-enriched supernatants was added to $5 \times 10^{4}$ freshly isolated autologous B cells in microtiter wells. Ten 


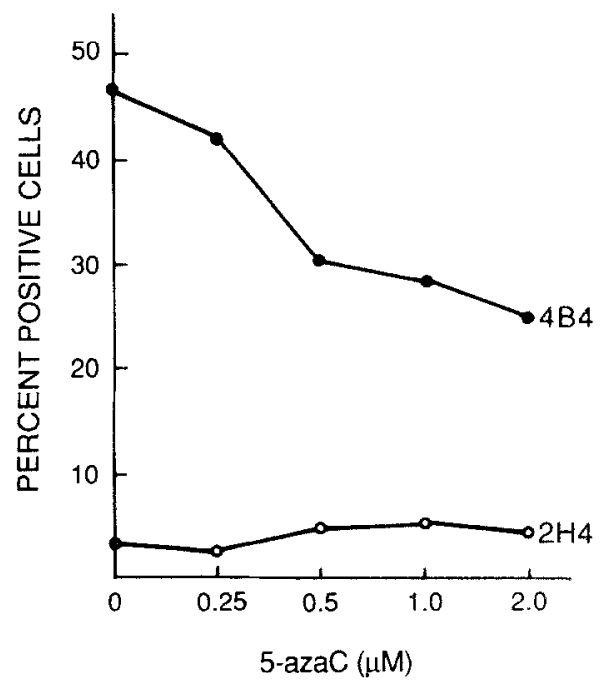

Fig. 3. Effect of 5-azaC on $2 \mathrm{H} 4$ (CD45R) and 4B4 (CDw29) expression. IL-2-dependent CD4 + cells were treated with the indicated concentrations of 5 -azaC and 6 days later were stained with anti2H4-FITC or anti-4B4-FITC, then analyzed by flow cytometry.

days later the supernatants were recovered and secreted IgG was measured by ELISA as before (Table 2). B cells cultured with media alone secreted less than $15 \mathrm{ng} / \mathrm{ml} \mathrm{IgG}$, and the T cell supernatants also contained less than $15 \mathrm{ng} / \mathrm{ml} \mathrm{lgG}$. B cells cultured with supernatants from freshly isolated, unstimulated CD4 + cells from the same $\mathrm{T}$ cell donor secreted $27.5 \mathrm{ng} / \mathrm{ml} \mathrm{IgG}$. In contrast, B cells cultured in supernatants from proliferating, IL-2-dependent, CD4 + cell lines secreted 1050

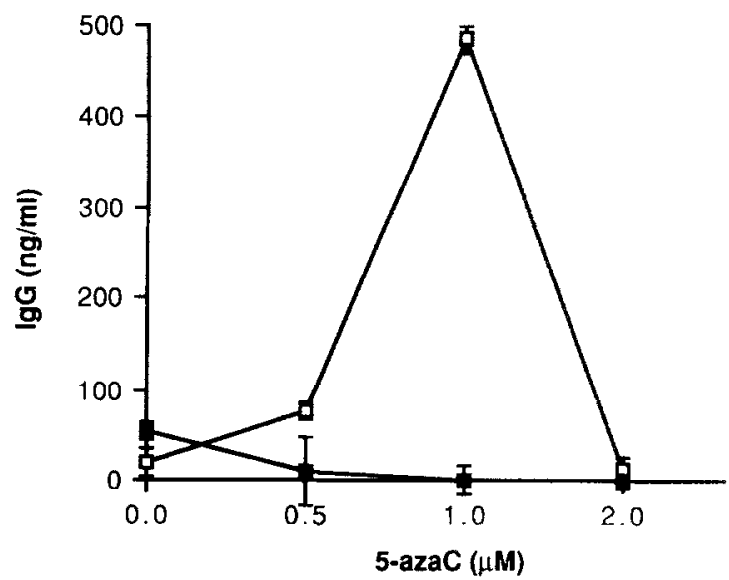

Fig. 4. 5-azaC-treated CD4 + cells induce autologous B cell differentiation. IL,-2-dependent CD4 + $(O)$ and $C D 8+(O)$ lines were treated with the indicated concentrations of 5-azaC. Six days later the cells were washed and cultured an additional 2 days without IL-2. T cells $\left(5 \times 10^{4}\right)$ were then cultured with $1.25 \times 10^{4}$ freshly isolated autologous B cells for 10 days in $200 \mu \mathrm{RPMI} / 10 \% \mathrm{FCS}$ in quadruplicated cultures. Supernatants were then harvested and IgG was measured by ELISA. The results represent the means \pm SEM of quadruplicate determinations. 
TABLE 2

Supernatants from Activated CD4 + Cells Activate Autologous B Cells

\begin{tabular}{cc}
\hline T cell supernatant $^{a}$ & $\operatorname{IgG}(\mathrm{ng} / \mathrm{ml})^{b}$ \\
& $<15$ \\
Unstimulated CD4 & $27.5 \pm 3.4$ \\
Stimulated CD4+ & $1025 \pm 125$ \\
5-azaC treated, stimulated CD4+ & $975 \pm 125$ \\
\hline
\end{tabular}

“Freshly isolated CD4 + cells obtained from the same donor as the CD4 + lines, IL-2-dependent CD4 + cells, or $1 \mu M$ 5-azaC-treated IL-2-dependent CD4 + cells were cultured for 2 days in RPMI/ $10 \%$ FCS. Supernatants from the T cells were then added to freshly isolated autologous B cells as described in Fig. 4.

${ }^{b}$ Results represent the means \pm SEM of quadruplicate determinations.

$\mathrm{ng} / \mathrm{ml} \mathrm{IgG}$, and B cells cultured in supernatants from $1 \mu M$ 5-azaC-treated, proliferating, IL-2-dependent CD4 + cell lines secreted $975 \mathrm{ng} / \mathrm{ml} \mathrm{IgG}$, indicating that $B$ cell differentiation can be induced by supernatants from activated CD4 + lines, regardless of 5-azaC treatment.

These results suggested that 5 -azaC-treated $\mathrm{T}$ cells could be activated by autologous $\mathrm{B}$ cells and in turn could activate the $\mathrm{B}$ cclls by secreted lymphokines. To test whether 5-azaC-treated $\mathrm{CD} 4+$ cells were activated by the B cells, experiments similar to those reported in Table 1 were performed, but using $B$ cells rather than PBMC. Treated and untreated CD4 + cells were cultured with irradiated $(2000 \mathrm{R})$ autologous $\mathrm{B}$ cells with and without anti-CD3 mAbs, and proliferation was measured 3 days later by $\left[{ }^{3} \mathrm{H}\right] \mathrm{TdR}$ incorporation. The response of untreated $\mathrm{CD} 4+$ cells to autologous B cells alone was $6597 \pm 721 \mathrm{cpm}$ (mean \pm SEM of quadruplicate determinations), and the response of the same cells to $B$ cells plus anti-CD3 was $12,522 \pm 1080 \mathrm{cpm}$. In contrast, the response of 5 -azaC-treated CD4 + cells to $B$ cells alone was $11,125 \pm 695 \mathrm{cpm}$, while the response to $B$ cells and anti-CD3 was $11,248 \pm 66 \mathrm{cpm}$, resembling the results presented in Table 1. In these experiments, $\left[{ }^{3} \mathrm{H}\right] \mathrm{TdR}$ incorporation by treated and untreated CD4 cells cultured alone was less than $1700 \mathrm{cpm}$. These results suggested that 5 -azaC treatment could make the $T$ cells respond to autologous B cells and secrete lymphokines.

Alternatively, 5-azaC treatment could cause prolonged lymphokine secretion, producing the $\mathrm{B}$ cell differentiation observed in coculture experiments. This possibility was examined by treating CD4 + cells with $1 \mu M 5$-azaC, and 6 days later the cells were washed free of IL-2. Treated and untreated cells were resuspended in RPMI/10\% FCS and supernatants were collected between 0 and 12, 12 and 24, 24 and 36, and 36 and $48 \mathrm{hr}$ after removal of IL-2. The supernatants were then added to cultured autologous B cells as before, and 10 days later secreted IgG was measured. Supernatants from treated and untreated cells collected 0-12 hr after removal of IL-2 produced B cell differentiation, while supernatants collected at later times did not. These results indicate that 5 -azaC treatment does not result in prolonged lymphokine secretion.

We next compared the effect of other DNA methylation inhibitors on $T$ cells using the $\mathrm{B}$ cell differentiation assay. Table 3 summarizes the results of experi- 
TABLE 3

5-azaC- and Procainamide-Treated CD4 Cells Induce Autologous B Cell Differentiation

\begin{tabular}{ccc} 
Drug $^{\alpha}$ & IgG $\left(\mathrm{ng} / \mathrm{ml}^{h}\right.$ & $P^{\circ}$ \\
\hline 5-azaC & $447 \pm 76$ & $<0.02$ \\
Procainamide & $234 \pm 52$ & $<0.05$ \\
Napa & $106 \pm 18$ & - \\
Hydroxyurea & $125 \pm 20$ & N.S. \\
- & $116 \pm 21$ & $\cdots$
\end{tabular}

${ }^{a} \mathrm{CD} 4$ cells were treated with $0.5-2.0 \mu M$ 5-azaC, $10 \mu M$ hydroxyurea, $10 \mu M$ procainamide, $10 \mu M$ Napa, or left untreated ( $\longrightarrow$ ), then cultured with autologous B cells as described in Fig. 4

${ }^{b}$ Results represent the means \pm SEM of the IgG response of three independent experiments, each performed in quadruplicate, comparing $0.5-2.0 \mu M$ 5-azaC and $10 \mu M$ hydroxyurea with untreated cells, and five experiments comparing $10 \mu M$ procainamide and $10 \mu M$ Napa.

${ }^{c}$ Results of 5-azaC-and hydroxyurea-treated cells were compared to those obtained with untreated cells and results from procainamide-treated cells were compared to those from Napa-treated cells. $P$ values were determined using Student's $t$ test. N.S., not significant.

ments comparing B cell differentiation induced by 5-azaC, procainamide, Napa, hydroxyurea, and untreated CD4 + cells. Hydroxyurea is a DNA synthesis inhibitor that does not inhibit DNA methylation (26), and procainamide is a more potent inducer of $\mathrm{T}$ cell autoreactivity than Napa (11). CD4 + cells were treated with 0.5-2.0 $\mu M$ 5-azaC, $10 \mu M$ hydroxyurea, $10 \mu M$ procainamide, or $10 \mu M$ Napa, then cultured with autologous B cells as before. The highest concentration in which IL-2-dependent cells can survive was previously shown to be $10 \mu M$ hydroxyurea (19), and $10 \mu M$ procainamide induces autoreactivity while $10 \mu M$ Napa does not (11). 5-azaC- and procainamide-treated CD4 + cells, but not hydroxyurea- or Napa-treated or untreated CD4 + cells, induced significant B cell differentiation, as evidenced by IgG secretion.

Since procainamide induces antilymphocyte (27) and antinuclear antihodies (28) in vivo, we tested whether IgG induced by 5 -azaC- and procainamide-treated $\mathrm{CD} 4+$ cells contained similar autoantibodies. IgG containing supernatants from $\mathrm{B}$ cells activated by procainamide- and 5-azaC-treated $\mathrm{T}$ cells were tested for antiDNA antibodies using a radioimmunoassay which detected $0.1 \mathrm{ng} / \mathrm{ml}$ of anti-DNA antibodies in control antisera and none were detected. Antihistone antibodies were sought using a radioimmunoassay which detected $0.5 \mathrm{ng} / \mathrm{ml}$ control antihistone antibody, and no antihistone antibodies were detected in the B cell supernatants. Finally, antilymphocyte antibodies were sought using a protein AELISA technique capable of detecting $1 \mathrm{ng} / \mathrm{ml}$ of anti-CD2, using the CD4 + line as target, and no antilymphocyte antibodies were detected (data not shown). All studies were performed using supernatants containing $300-1000 \mathrm{ng} / \mathrm{ml} \mathrm{IgG}$.

In all the studies presented IgM was also measured. While 5-azaC-treated $\mathrm{CD} 4+$ cells also induced IgM secretion, the magnitude of the IgM response varied widely between experiments, possibly reflecting donor effects (data not shown).

\section{DISCUSSION}

These experiments demonstrate that 5 -azaC-treated polyclonal $\mathrm{CD} 4+\mathrm{T}$ cell 
lines respond to autologous PBMC, and that CD4 + cells treated with DNA methylation inhibitors induce differentiation in autologous $B$ cells without the addition of mitogen or specific antigen.

Untreated CD4 + and CD8 + lines demonstrated a small proliferative response to autologous irradiated PBMC, which presumably is the autologous mixed lymphocyte reaction (24). 5-azaC treatment markedly augmented this response in CD4 + lines, but did not alter the CD8 + response. Mixing studies using treated CD4 and CD8 + cells demonstrated that the failure of CD8 + cells to respond to autologous PBMC was not due to a lack of CD4 + cells. The CD8 + cells did not suppress the CD4 response, probably due to difficulties in maintaining suppressor cells in long term lines (29). The CD4 + response was inhibited with monoclonal antibodies to class II but not class I MHC determinants, suggesting that the cells could be responding to autologous HLA-D determinants on the PBMCs. These results are similar to previously published experiments in which 5-azaC-treated, cloned tetanus toxoid-specific CD4 $+\mathrm{T}$ cells lost the requirement for antigen and could be activated by autologous class II determinants alone (9), while 5azaC-treated, cloned CD8 + antigen-specific cells did not demonstrate a similar altered reactivity (19). It is reasonable to propose that 5 -azaC is inducing autoreactivity in the polyclonal CD4 + lines by the same mechanism that autoreactivity is induced in cloned lines. In other experiments using 5-azaC-treated cloned CD4 + cells, the autoreactive response was inhibited with $\mathrm{mAb}$ to CD2, CD11a, and ICAM-1, but not CD4 (30), suggesting that molecules of the integrin family are also involved in this response.

Alternatively, in these experiments, 5-azaC treatment may select for AMLR responsive cells in polyclonal lines. Recent reports indicate that AMLR responsive cells are primarily found in the $\mathrm{CD} 4+2 \mathrm{H} 4+$ population (25). Therefore, we tested whether 5 -azaC altered the percentage of $2 \mathrm{H} 4+(\mathrm{CD} 45 \mathrm{R})$ and $4 \mathrm{~B} 4+$ (CDw29) cells in the polyclonal lines. The untreated lines contained mostly $2 \mathrm{H} 4-$ cells. The low percentage of $2 \mathrm{H} 4+$ cells in the untreated lines probably represents loss of the $2 \mathrm{H} 4$ determinant in these IL-2-dependent lines (31). 5-azaC treatment did not increase the percentage of $2 \mathrm{H} 4+$ cells, indicating that 5 -azaC is not selecting this $\mathrm{T}$ cell subset. Interestingly, CD $4+2 \mathrm{H} 4+$ cells are also diminished in the peripheral blood of SLE patients (32). Furthermore, other investigators have reported that CD4+ AMLR responsive cells provide help to AMLR responsive CD8 + cells $(33,34)$. This is not the case in this system, also arguing against a selection for AMLR responsive cells.

While the mechanism by which 5 -azaC alters the activation requirements of CD4 + cells remains uncertain, the response appears to have functional significance since 5-azaC-treated $\mathrm{CD} 4+$ cells reproducibly induced differentiation in autologous B cells without the addition of exogenous antigen or mitogen. $\mathrm{Hy}$ droxyurea-treated CD4 + cells failed to induce B cell differentiation, consistent with previous observations that hydroxyurea does not induce autoreactivity in cloned CD4 + cells (9). T cells treated with $10 \mu M$ procainamide also activated B cells, but $T$ cells treated with $10 \mu M$ Napa did not. The procainamide-treated cells presumably induced $\mathrm{B}$ cell differentiation via a mechanism similar to 5 -azaC since cloned $T$ cells treated with $10 \mu M$ procainamide become autoreactive, while cells 
treated with $10 \mu M$ Napa do not (11). Significantly, this procainamide concentration is close to that achieved therapeutically in vivo (35) and may play a role in the $B$ cell activation found in patients with active procainamide-induced SLE (13).

DNA methylation inhibitors administered in vivo could also thcorctically directly induce $B$ cell differentiation. However, we have treated the $B$ cell line RPMI 4265 as well as Epstein-Barr transformed B cells with 5-azaC and found no change in IgG or IgM secretion or in expression of surface Ig (unreported observations). This suggests that a direct effect of DNA methylation inhibitors on $B$ cclls is unlikely to be a mechanism responsible for B cell activation.

Supernatants from activated 5-azaC-treated as well as untreated CD4 + cells induced $B$ cell differentiation, indicating that once the $T$ cells are activated, direct $\mathrm{B}$ cell binding is no longer required to induce $\mathrm{B}$ cell differentiation. The activated cells, being largely $2 \mathrm{H} 4-, 4 \mathrm{~B} 4+$, are presumably secreting lymphokines with $\mathrm{B}$ cell helper activity (36), such as IL-5 (37), IL-6 (38), or interferon- $\gamma(20)$. Studies identifying the relevant lymphokines are underway. Decay curves indicated that 5 -azaC treatment did not produce prolonged secretion of lymphokines. These results therefore suggest a mechanism for the $B$ cell differentiation observed when 5 -azaC-treated CD4 + cells are cultured with autologous B cells. In this model, $\mathrm{CD} 4+$ cells treated with DNA methylation inhibitors are activated by self determinants on B cells, or possibly on contaminating macrophages, and the activated $T$ cells secrete lymphokines which in turn induce B cell differentiation. This is supported by experiments demonstrating that 5 -azaC-treated $\mathrm{CD} 4+$ cells proliferate when challenged with autologous B cells. Since $T$ cells from patients with idiopathic SLE appear to have hypomethylated DNA, this model may also apply to idiopathic SLE. Other authors have reported isolating autoreactive, Ia-specific $\mathrm{T}$ cell lines which also induce $\mathrm{B}$ cell differentiation via secreted lymphokines ( 39 . 40 ), supporting this model. The relationship of these naturally occurring autoreactive cells to 5-azaC-treated cells remains to be determined.

Procainamide-induced and idiopathic SLE are also characterized by anti-DNA antihistone, and antilymphocyte antibodies $(27,28,41)$. These were sought in supernatants from $\mathrm{B}$ cells activated by 5 -azaC-and procainamide-treated $\mathrm{T}$ cells and none were found. If autoantibodies were synthesized, they were present in amounts too small to detect. The assays could detect nanogram amounts of autoantibodies, and the supernatants contained more than $100 \mathrm{ng} / \mathrm{ml}$ of IgG, indicating that any autoantibodies would account for less than $1 \%$ of the secreted IgG. However, the B cell donor in these experiments was a healthy volunteer without risk factors for autoimmune disease. In patients with autoimmune diseases or receiving procainamide, in vivo priming to nuclear antigens could occur $(42,43)$. Exposure to self-antigens in vivo, together with lymphokines supporting B cell differentiation, could enrich for autoantibody-secreting B cells in patients with SLE. It will be important to repeat these studies in patients with autoimmune diseases and controls to test this hypothesis. Furthermore, precursor frequency analysis for autoantibodies in idiopathic SLE indicates that B cells making antiDNA antibodies are present at approximately 0.36 per $10^{6} \mathrm{PBMC}(44)$, while there are approximately $4000 \mathrm{Ig}$-secreting cells $/ 10^{6} \mathrm{PBMC}$ in similar patients (45), suggesting that precursors for anti-DNA antibodies make up only a small fraction of 
the Ig made in active SLE. This could also explain the low level of autoantibodies found in this system.

\section{ACKNOWLEDGMENTS}

The authors thank Ms. Laura Gross and Ms. Camille Wilkinson for expert technical assistance, Ms. Ruth Douglas and Michele Thompson for superb secretarial support, and Dr. Joel Depper for reviewing this manuscript. This work was supported by grants from the NIH (AI2552G, AR20557) and the Michigan Chapter of the Arthritis Foundation.

\section{REFERENCES}

1. Rolink, A. G., and Gleichmann, E., Allosuppressor and allohelper-T cells in acute and chronic graft-vs.-host (GVH) disease. III. Different Lyt subsets of donor 'T cells induce different pathological syndromes. J. Exp. Med. 158, 546-558, 1983.

2. Gleichmann, E., Van Elven, E. H., and Van der Veen, J. P. W., A systemic SLE erythematosus (SLE)-like disease in mice induced by abnormal T-B cell cooperation: Preferential formation of autoantibodies characteristic of SLE. Eur. J. Immunol. 12, 152-159, 1982.

3. Eisenberg, R. A., and Cohen, P. L., Hypothesis: Class II major histocompatibility antigens and the etiology of systemic SLE erythematosus. Clin. Immunol. Immunopathol. 29, 1-6, 1983.

4. Russell, P. J., Doolan, T. J., Webb, J., and Carr, G. A., Studies of autologous mixed lymphocyte reactions in patients with systemic lupus erythematosus. Pathology 15, 37-43, 1983.

5. Sakane, T., Steinberg, A. D., and Green, I., Failure of autologous mixed lymphocyte reactions between $\mathrm{T}$ and non-T cells in patients with systemic lupus erythematosus. Proc. Natl. Acad. Sci. USA 75, 3464-3468, 1978.

6. Kuntz, M. M., Innes, J. B., and Weksler, M. E., The cellular basis of the impaired autologous mixed lymphocyte reaction in patients with systemic lupus erythematosus. J. Clin. Invest. 63, 151-153, 1979.

7. Sakane, T., Steinberg, A. D., Arnett, F. C., Reinersten, J. L., and Green, I., Studies of immune functions of patients with systemic lupus erythematosus. III. Characterization of lymphocyte subpopulations responsible for defective autologous mixed lymphocyte reactions. Arthritis Rheum. 22, 770-776, 1979.

8. Silver, R. M., Redelman, D., and Zvaifler, N. J., Studies of rheumatoid synovial fluid lymphocytes. II. A comparison of their behavior with blood mononuclear cells in the autologous mixed lymphocyte reaction and response to TCGF. Clin. Immunol. Immunopathol. 27, 15-27, 1983.

9. Richardson, B., Effect of an inhibitor of DNA methylation on T cells. II. 5-azacytidine induces self-reactivity in antigen-specific T4 + cells. Hum. Immunol. 17, 456-470, 1986.

10. Cornacchia, E., Golbus, J., Maybaum, J., Strahler, J., Hanash, S., and Richardson, B., Hydralazine and procainamide inhibit T cell DNA methylation and induce autoreactivity. J. Immunol. 140, 2197-2200, 1988.

11. Richardson, B., Cornacchia, E., Golbus, J., Maybaum, J., Strahler, J., and Hanash, S., Nacetylprocainamide is a less potent inducer of $\mathrm{T}$ cell autoreactivity than procainamide. Arthritis Rheum. 31, 995-999, 1988.

12. Richardson, B. C., Strahler, J. R., Hanash, S. M., and Johnson, M., Evidence for impaired T cell DNA methylation in rheumatoid arthritis. Submitted for publication.

13. Forrester, J., Golbus, J., Brede, D., Hudson, J., and Richardson, B., B cell activation in patients with active procainamide induced lupus. $J$. Rheumatol. 15, 1384-1388, 1988.

14. Budman, D. R., Merchant, E. B., Steinberg, A. D., Doft, B., Gershwin, M. E., Lizzio, E., and Reeves, J. P., Increased spontaneous activity of polyclonal antibody-forming cells in the peripheral blood of patients with active SLE. Arthritis Rheum. 20, 829-833, 1977.

15. Yu, D. T. Y., McCune, J. M., Fu, S. M., Winchester, J., and Kunkel, H. G., Two types of Ia-positive T cells: Synthesis and exchange of la antigens. J. Exp. Med. 152, 89s, 1980.

16. Huang, Y.-P., Perrin, L. H., Miescher, P. A., and Zubler, R. H., Correlation of T and B cell activities in vitro and serum IL-2 levels in systemic lupus erythematosus. J. Immunol. 141, $827-833,1988$. 
17. Portanova, J. P., Claman, H. N., and Kotzin, B. L., Autoimmunization in murine graft-vs-host disease. I. Selective production of antibodies to histones and DNA. J. Immunol. 135, 3850-3856, 1985.

18. Rabin, H., Hopkins, R. F., III, Ruscetti, F. W., Neubauer, R. H.. Brown, R. L., and Kawakam, $T$. G., Spontaneous release of a factor with properties of $T$ cell growth factor from a continuous line of primate tumor T cells. J. Immunol. 127, 1852-1856, 1981

19. Richardson, B., Kahn, L., Lovett, E. J., and Hudson, J., Effect of an inhibitor of DNA methylation on T cells. I. 5-azacytidine induces T4 expression on T8 + T cells. J. Immunol. 137, 3539. 1986.

20. Golbus, J., Salata, M., Greenwood, J., Hudson, J., and Richardson, B. C.. Increased immunoglobulin response to $\gamma$-interferon by lupus erythematosus. Clin. Immunol. Immunopathol. 46. 129-140, 1988.

21. Liebling, M. R., Wong, C., and Radosevich, J., Spontaneous in vitro production of anti-DNA and anti-RNA by systemic lupus erythematosus and normal peripheral blood mononuclear cells. Arthritis Rheum. 28, 431-440, 1985.

22. Rubin, R. L., McNally, E. N., Nusinow, S. R., Robinson, C. A., and Eng, E. M., IgG antibodies to the histone complex H2A-H2B characterize procainamide-induced lupus. Clin. Immunot. Immunopathol. 36, 49-59, 1985.

23. Todd, R. F., III. Meurer, S. C.. Romain, P. L., and Schlossman, S. F., A monoclonal antibody that blocks class II histocompatibility-related immune interactions. Hum. Immunol. 10, 23-40, 1984.

24. Weksler, M. E.. Moody, C. E. Jr.. and Kozak, R. W.. The autologous mixed-lymphocyte reaction. In "Advances in Immunology" (H. G. Kunkel and F. J. Dixon, Eds.), Vol. 31, pp. 271-312. Academic Press, New York, 1981.

25. Takeuchi, T., Rudd, C. E., Schlossman, S. F., and Morimoto, C.. Induction of suppression following autologous mixed lymphocyte reaction; role of a novel $2 \mathrm{H} 4$ antigen. Eur. J. Immunol. $17,97-103,1987$.

26. Nyce, J., Liu, L., and Jones, P. A., Variable effects of DNA-synthesis inhibitors upon DNA methylation in mammalian cells. Nucl. Acids Res. 14, 4353-4367. 1986.

27. Bluestein, H. G., Redelman, D., and Zvaifler, N. J., Procainamide-lymphocyte reactions: A possible explanation for drug-induced autoimmunity. Arthritis Rheum. 24, 1019-1023, 1981.

28. Harmon, C. E., and Portanova. J, P., Drug-induced lupus: Clinical and serological studies. Clin. Rheum. Dis. 8, 121-135, 1982.

29. Mohagheghpour, N., Damle, N. K., Takada, S., and Engleman, E. G., Generation of antigen receptor-specific suppressor T cell clones in man. J. Exp. Med. 164, 950-955, 1986.

30. Richardson, B., Strahler, J., Pivirotto, T. S., Hudson, J. L., and Hanash, S. M., The role of LFA-1 in 5-azacytidine induced T cell autoreactivity. Submitted for publication.

31. Akbar, A. N.. Terry, L., Timms, A., Beverley, P. C. L., and Janossy, G., Loss of CD45R and gain of UCHL-1 reactivity is a feature of primed T cells. J. Immunol. 140, 2171. 1988.

32. Sato. S.. Miyasaka, N., Yamaoka. K., Okuda, M., Yata. J.. and Nishioka, K., Quantitative defect of CD4 $+2 \mathrm{H} 4+$ cells in systemic lupus erythematosus and Sjogren's Syndrome. Arthritis Rheum. 30, 1407-1411, 1987.

33. Romain, P. L.. Schlossman, S. F., and Reinherz, E. L. Surface molecules involved in selfrecognition and $\mathrm{T}$ cell activation in the autologous mixed lymphocyte reaction. $J$. Immunol. 133, 1093-1100, 1984.

34. Smolen, J. S., Luger, T. A., Chusen, T. M., and Steinberg, A. D.. Responder cells in the human autologous mixed lymphocyte reaction. J. Clin. Invest. 68, 1601-1604, 1981.

35. Sonnhag, C.. Karlsson, E., and Hed. J., Procainamide-induced lupus erythematosus-like syndrome in relation to acetylator phenotype and plasma levels of procainamide. Acta Med. Scand. 206, 245-251, 1979.

36. Morimoto, C., Letvin, N. L., Distaso, J. A., Aldrich, W. R., and Schlossman, S. F., The isolation and characterization of the human suppressor inducer T cell subset. J. Immunol, 134, 15081515, 1985.

37. Azuma, C., Tanabe, T., Konishi, M., Kinash, T., Noma, T., Matsuda, F., Yaoita, Y., Takatsu. K., Hammarstrom, L., Smith, C. I. E., Severinson, E.. and Honjo. T.. Cloning of cDNA for 
human T-cell replacing factor (interleukin-5) and comparison with the murine homologue. Nucl. Acids Res. 14, 9149-9158, 1986.

38. Hirano, T., Taga, T., Nakano, N., Yasukawa, K., Kashiwamura, K., Shimizu, K., Nakajima, K., Pyun, K. H., and Kishimoto, T., Purification to homogeneity and characterization of human B-cell differentiation factor (BCDF or BSFp-2). Proc. Natl. Acad. Sci. USA 82, 5490-5494, 1985.

39. Clayberger, C., Dekruyff, R. H., and Cantor, H., Immunoregulatory activities of autoreactive T cells: An I-A-specific T cell clone mediates both help and suppression of antibody responses. $J$. Immunol. 132, 2237-2243, 1984.

40. Saito, T., and Rajewsky, K., A self-Ia reactive T cell clone directly stimulates every hundredth B cell and helps antigen-specific B cell responses. Eur. J. Immunol. 15, 927-934, 1985.

41. Notman, D. D., Kurata, N., and Tan, E. M., Profiles of antinuclear antibodies in systemic rheumatic diseases. Ann. Int. Med. 83, 464-469, 1975.

42. Portanova, J. P., Arndt, R. E., Tan, E. M., and Kotzin, B. L., Anti-histone antibodies in idiopathic and drug-induced lupus recognized distinct intrahistone regions. J. Immunol. 138, 446-451. 1987.

43. Craft, J. E., Radding, J. A., Harding, M. W., and Bernstein, R. M., Autoantigenic histone epitopes: A comparison between procainamide- and hydralazine-induced lupus. Arthritis Rheum. 30, 689-694, 1987.

44. Hoch, S., Schur, P. H., and Schwaber, J., Frequency of anti-DNA antibody producing cells from normals and patients with systemic lupus erythematosus. Clin. Immunol. Immunopathol. 27, 28-37, 1983.

45. Fauci, A. S., and Moutsopoulos, H. M., Polyclonally triggered B cells in the peripheral blood and bone marrow of normal individuals and in patients with systemic lupus erythematosus and primary Sjogren's syndrome. Arthritis Rheum. 24, 577-584, 1981.

Received September 21, 1989; accepted with revision January 17, 1990 